\title{
PEMANFAATAN MEDIA LIFT THE FLAP BOOK UNTUK MENINGKATKAN KEMAMPUAN MEMBACA
}

\author{
THE UTILIZATION OF LIFT THE FLAP BOOK MEDIA FOR IMPROVING \\ OF READING ABILITY
}

\author{
Yuli Triyanto ${ }^{a}$ Enny Zubaidah ${ }^{b}$
}

\author{
Program Pasca Sarjana, Universitas Negeri Yogyakarta ${ }^{a}$ \\ Fakultas Ilmu Pendidikan, Universitas Negeri Yogyakarta ${ }^{b}$ \\ Karangmalang, Yogyakarta, Indonesia 55281 \\ yulitriyanto.2018@student.uny.ac.id; enny_zubaidah@uny.ac.id
}

(Naskah diterima tanggal 21 Agustus 2020, direvisi terakhir tanggal 4 Februari 2021, dan disetujui tanggal 3 Mei 2021)

DOI: https://doi.org/10.26499/wdprw.v49i1.627

\begin{abstract}
This research is about the reading skills of the grade I students and the method is classroom action research by doing classroom study using lift the flap book media. The purpose of the research is to improve the reading skills of the grade I students of SD Negeri Puren Depok Sleman using the lift the flap book media. Learning to read in grade I SD Negeri Puren is still not in accordance with the expected results. Evidenced by the results of reading skills, there are still many who have not reached the complete score. The results showed that the use of lift the flap book media can improve student's reading skills. This can be seen from the increase in the learning process on each indicator of reading ability. Students are increasingly interested in learning, and teachers have used other media besides books from school. The process of learning to read has increased, namely that the average score increase from cycle 1 the score is 76 and cycle 2 the score is 83. Students whose average score are above the average increase from cycle 1 by $46.4 \%$ and cycle 2 as much as $85 \%$.
\end{abstract}

Keyword: reading ability; lift the flap book

\begin{abstract}
Abstrak
Penelitian yang dilakukan ini tentang kemampuan membaca siswa kelas 1, dan metode yang digunakan adalah penelitian tindakan kelas (classroom action research) dengan melakukan pembelajaran di dalam kelas menggunakan media lift the flap book. Tujuan penelitian adalah kemampuan membaca siswa kelas 1 SD Negeri Puren Depok meningkat dengan menggunakan bantuan media lift the flap book. Kegiatan belajar mengajar membaca di SD Negeri Puren kelas I hasilnya masih belum sesuai dengan yang diharapkan. Terbukti dengan kemampuan membaca masih banyak yang nilainya belum sesuai yang diharapkan. Hasil penelitian kemampuan membaca meningkat setelah menggunakan media lift the flap book hal ini dapat diketahui meningkatnya pada proses pembelajaran pada setiap indikator kemampuan membaca. Siswa semakin tertarik mengikuti pembelajaran, dan guru sudah menggunakan media lain selain buku dari sekolah. Proses pembelajaran membaca mengalami peningkatan yaitu nilai rata-rata meningkat dari siklus 1 nilainya 76 dan siklus 2 nilainya 83. Siswa yang nilainya di atas rata-rata meningkat dari siklus 1 sebanyak $46,4 \%$ dan siklus 2 sebanyak $85 \%$.
\end{abstract}

Kata-kata Kunci: kemampuan membaca; siswa kelas 1; lift the flap book 


\section{Pendahuluan}

Setiap individu akan melakukan komunikasi dan bahasa merupakan salah satu sarana untuk berkomunikasi. Kemampuan berbahasa pertama dari seorang individu salah satunya adalah membaca. Siswa kelas 1 SD Negeri Puren kemampuan membacanya masih rendah. Berdasarkan pengamatan secara langsung dari 28, baru 10 siswa yang mampu membaca dengan baik.

Penelitian ini difokuskan pada peningkatan kemampuan mambaca siswa SD Negeri Puren kelas 1 dengan menggunakan media lift the flap book. Penelitian ini bertujuan untuk meningkatkan kemampuan membaca siswa kelas 1 SD Negeri Puren. Manfaatnya adalah berkontribusi terhadap pembelajaran untuk meningkatkan kemampuan membaca dengan menggunakan media pembelajaran.

Informasi yang disampaikan tersimpan dengan baik jika berbahasa dengan baik, dan selama perkembangan bahasa, anak belajar membaca (Sudharsan, 2018: 2). Kegiatan membaca merupakan proses transaktf, pembaca menegosiasikan makna atau menginterpretasikan (Tomkins, Geil \& Hoskisson, 1995: 198).

Kemampuan membaca dapat meningkat apabila seseorang bisa menjadikan kebiasaan membaca sebagai sebuah pola pikir yang spesifik. Pengembangan ilmu dan teknologi serta pembangunan peradaban manusia syarat pertama serta utama adalah membaca dengan beberapa maknanya. Pada hakikatnya membaca merupakan kegiatan secara fisik. Kegiatan ini bertujuan menemukan makna tulisan. Kegiatan membaca terjadi proses mengenalkan huruf-huruf (Petscher, dkk., 2017: 14).

Bagi siswa sekolah dasar kelas 1, membaca merupakan pembelajaran tahap awal untuk menguasai dan memperoleh kemampuan teknik membaca dan menangkap isi bacaan dengan baik, aktivitasnya membaca keras, memahami dan mencocokkan gambar dengan kata, menceritakan kembali dan menyelesaikan kalimat setelah mendengar dan membaca (Suggate, 2009: 123).

Kegiatan membaca melibatkan siswa secara aktif dengan teks bacaan, memahami makna dari bacaan tersebut melalui kegiatan mengubah bentuk tulisan ke dalam bunyi yang bermakna. Penjelasan perbedaan dalam mengucapkan pepet /e/ fonem (misalnya pada kata kera atau sembilan) dan /e/ biasa (pada kata boleh), hal-hal yang dapat dilakukan untuk mempersiapkan siswa dalam membaca yaitu dengan mengakrabkan siswasiswa dengan buku dan bentuk cetak lainnya, membiasakan siswa mengamati orang membaca dan menulis sebagai bagian dari kehidupan sehari-hari (Cowie, 2010: 111; Konza, 2014: 157; Kucukoglu, 2013: 710).

Proses kegiatan pembelajaran membaca dapat dibantu dengan media pembelajaran. Media pembelajaran adalah sarana pendidikan dan digunakan sebagai perantara dan dapat meningkatkan dalam proses pembelajaran, dan dapat menyampaikan materi dalam kegiatan pembelajaran (Widodo, 2018: 159). Penggunaan media berupa pop-up dapat meningkatkan proses pembelajaran serta meningkatkan hasil proses kemampuan membaca.

Kegiatan pembelajaran di SD Puren media lift the flap book belum dimanfaatkan. Salah satu media yang dapat digunakan adalah bu$\mathrm{ku}$, lift the flap book merupakan jenis media yang berbentuk buku. Media pembelajaran lift the flap book adalah salah satu jenis buku yang bersifat interaktif dengan beberapa halaman bukunya harus dibuka untuk mengetahui kejutan di balik halamannya, secara tidak langsung dapat melatih perkembangan motorik pada anak-anak dengan kegiatan melihat, membuka dan menutup buku (Oey, dkk., 2011: 4). 
Media berupa lift the flap book termasuk dalam kelompok buku pop up yang menarik bagi peserta didik. Buku pop up merupakan buku penuh warna dan kreatif sehingga itu menyenangkan bagi pembaca dari segala usia (Bluemel \& Taylor, 2012: 16). Buku interaktif dengan tab dan flap yang biasa ilustrasi 3-D, buku pop-up akan membuat pembaca ingin membalik halaman untuk menangkap sekilas isi berikutnya. Media pop-up mampu dalam memperkuat kesan dari cerita yang disampaikan oleh guru (Fajarsih Darusuprapti, Haryanto, 2019: 76).

Teori yang mendasari penggunaan lift the flap book adalah teori perkembangan anak. Depdiknas menyampaikan sebagai berikut: 1) tujuan pembelajaran yang akan dicapai; 2) kemudahan penggunaan media; 3) metode pembelajaran yang akan digunakan; 4) sesuai dengan taraf berpikir siswa. dan kemampuan tutor dalam menggunakannya; 5) ketersediaan waktu; dan 6) karakteristik peserta didik meliputi ragam media, kemampuan bahasa, kemampuan baca tulis, usia, dan jenis kelamin (Depdiknas, 2018: 11).

Beragam media yang dapat dipilih untuk dapat digunakan dalam proses pembelajaran. Hasil penelitian Martin-Kerry dkk, melaporkan dalam pembelajaran partisipasi siswa dapat ditingkatkan dengan media gambar (Martin-Kerry dkk, 2017: 10). Penelitian Rasch \& Schnotz, menunjukkan bahwa partisipasi dalam kegiatan pembelajaran dapat ditingkatkan dengan media gambar (2009: 421).

Setiap media agar cara menggunakan berbeda-beda, begitu juga lift the flap book memiliki cara penggunaan sendiri. Langkah langlah penggunaan lift the flap book: 1) digunakan di ruang kelas, perpustakaan atau di homeschool, untuk menarik perhatian anakanak. 2) tema-tema dalam buku dapat dikaitkan atau digunakan untuk materi pelajaran lainnya, misalnya tema keagamaan dapat digunakan untuk pembelajaran matematika atau sain. 3) kegiatan dengan buku lift the flap book disesuaikan dengan kebutuhan siswa, kelas dan pembelajaran yang dilakukan (Bluemel \& Taylor, 2012: 12).

Berdasarkan urian permasalahan, serta kajian-kajian toeri di atas peneliti tertarik untuk meneliti tentang kemampuan mambaca siswa kelas I. Permasalahan dalam penelitian ini adalah kemampuan membaca berdasarkan aspek lafal, intonasi, kelancaran, kejelasan, membaca dengan utuh. Media pembelajaran berupa lift the flap book merupakan media yang digunakan untuk peningkatan proses belajar dan kemampuan membaca siswa kelas I Sekolah Dasar Negeri Puren Depok Sleman.

\section{Metode}

Penelitian ini dikemas dalam bentuk classroom action research atau penelitian tindakan kelas. Penelitian tindakan kelas (PTK) merupakan penelitian yang praktis, dimaksudkan untuk memperbaiki proses pembelajaran atau meningkatkan hasil proses pembelajaran di dalam kelas. PTK adalah penelitian dilakukan dengan penekanan pada penyempurnaan atau peningkatan proses pembelajaran. Penelitian ini memanfaatkan media lift the flap book yang bertujuan meningkatkan kemampuan proses pembelajaran dan hasil proses pembelajaran kemampuan membaca. Tujuan tersebut dapat dicapai dengan tidakan yang dilakukan untuk mengatasi permasalahnpermasalahan dalam proses pembelajaran di dalam kelas. Penelitian Tindakan Kelas atau PTK ada 4 tahapan yaitu: Planning (perancanaan), Acting (pelaksanaan), Observing (pengamatan), dan Reflexing (refleksi) (Arikunto, 2008: 16).

Penelitian tindakan kelas (PTK) dengan alur pelaksanaan digambarkan sebagai berikut: 


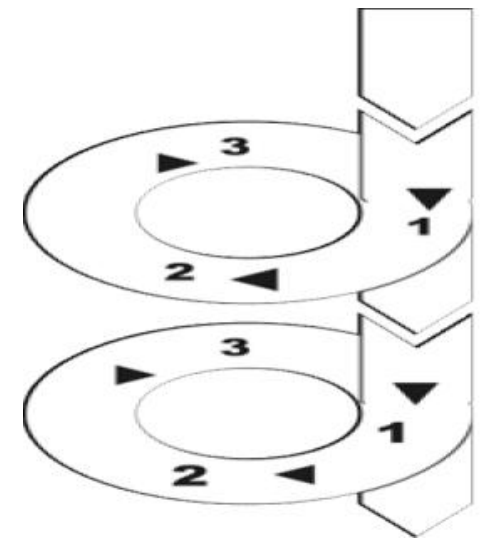

Gambar. Model Spiral Kemmis dan Mc.Taggart

Setiap tahapan tersebut dapat dijelaskan sebagai berikut: 1) Tahap pertama menyusun rancangan tindakan (planning). Pada tahap ini guru menyusun rancangan tindakan yang dilakukan, meliputi tindakan yang akan dilakukan, waktu pelaksanaan tindakan, dan menyusun instrument pengamatan untuk mendapatkan fakta yang terjadi selama dilaksanakan penelitian. 2) Tahap kedua pelaksanaan tindakan (action) dan observasi (observing). Tahap ini merupakan implementasi dari rancangan yang sudah dibuat, dilakukan di kelas dengan tindakan yang wajar dan tidak dibuat-buat. Pada tahap tindakan ini sekaligus dengan observasi (observing). 3) Tahap ketiga refleksi (reflecting). Pada tahap ketiga merupakan kegiatan merefleksikan kegiatan yang telah dilakukan selanjutnya hasil refleksi digunakan untuk membuat rancngan. Rancangan digunakan untuk melakukan kegiaatan di siklus selanjutnya.

Penelitian yang dilakukan sebagai subjeknya adalah semua siswa SD Negeri Puren kelas I. Jumlah siswa kelas I SD Negeri Puren Depok Sleman adalah 28 siwa dengan rincian laki-laki 17 siswa dan perampuan 11 siswa.

Objek dari penelitian ini adalah proses kegiatan pembelajaran membaca dan kemampuan membaca pada siswa SD Negeri Puren Depok kelas I Sleman menggunakan media lift the flap book.
Karakteristik subyek penelitian kemampuan membaca yang meliputi lafal, intonasi, kelancaran, kejelasan, dan membaca dengan utuh, baru dua aspek yang dikuasi siswa yaitu kelancaran sebanyak 12 siswa dan kejelasan sebanyak 11 siswa. Waktu pelaksanaan penelitian ini pada bulan Januari sampai dengan Maret tahun 2020. Pengumpulan data yang digunakan dalam penelitian adalah variabel kemampuan membaca menggunakan tes unjuk kerja. Tes untuk mengukur sejauh mana peningkatan kemampuan membaca siswa pada setiap siklusnya. Tes diberikan kepada seluruh siswa pada pertemuan kedua setiap siklusnya. Pengamatan proses pembelajaran dilakukan dengan observasi terhadap guru dan siswa, observasi dalam penelitian ini adalah mengamati secara langsung dengan cermat terhadap: (a) Proses tindakan, (b) Hasil dari tindakan, (c) Kendala dan hambatan untuk merencanakan tindakan berikutnya. Pedoman penilaian kemampuan membaca dibuat untuk memudahkan dalam melakukan penelitian.

\section{Tabel 1}

Kisi-kisi Pedoman Observasi Kegiatan Pembelajaran Siswa dan Guru

\begin{tabular}{|c|c|c|c|c|}
\hline \multirow{2}{*}{ No } & \multirow{2}{*}{$\begin{array}{c}\text { Aspek yang } \\
\text { diamati }\end{array}$} & \multicolumn{2}{|c|}{ Item pengamatan } & \multirow{2}{*}{$\begin{array}{l}\text { Jumlah } \\
\text { iem }\end{array}$} \\
\hline & & Guru & Siswa & \\
\hline 1. & $\begin{array}{l}\text { Kegiatan } \\
\text { awal }\end{array}$ & $\begin{array}{l}\mathrm{a}, \mathrm{b}, \mathrm{c}, \\
\mathrm{d}, \mathrm{e}, \mathrm{f}\end{array}$ & - & 6 \\
\hline 2. & $\begin{array}{l}\text { Kegiatan } \\
\text { inti }\end{array}$ & $\mathrm{d}, \mathrm{e}, \mathrm{f}$ & $a, b, c$ & 6 \\
\hline 3. & $\begin{array}{l}\text { Kegiatan } \\
\text { akhir }\end{array}$ & $\mathrm{a}, \mathrm{c}, \mathrm{d}$ & $\mathrm{b}$ & 4 \\
\hline \multicolumn{4}{|c|}{ Jumlah } & 10 \\
\hline
\end{tabular}

Kisi-kisi panduan penilaian kemampuan membaca berdasarkan Depdiknas adalah sebagai berikut: 
Tabel 2

Kisi-kisi Tes Kemampuan Membaca

\begin{tabular}{llcc}
\hline Kompetensi Dasar & Indikator & $\begin{array}{c}\text { Bentuk } \\
\text { Soal }\end{array}$ & Item \\
\hline Membaca nyaring & Siswa & unjuk & 1 \\
teks dengan & mampu & kerja & \\
memperhatikan & membaca & & \\
indikator & teks pen- & & \\
penilaian & dek den- & & \\
& gan lafal, & & \\
& intonasi, & & \\
& lancar jelas & & \\
& dan mem- & & \\
& baca den- & & \\
& gan utuh & & \\
\end{tabular}

Depdiknas (2009: 129).

Setelah data terkumpul langkah selanjutnya adalah melakukan analisis data. Teknik analisis data menggunakan rerata dan persentase, dan kemudian dideskripsikan dengan cara membandingkan nilai rerata awal dan akhir pelaksanaan penelitian, serta mencari prosentase. Menurut W. James Pophan \& Kenneth A. Sirothik, (1973: 12), rata-rata diperoleh dengan menjumlahkan semua skor mentah dan membagi dengan jumlah yang dijumlahkan dengan jumlah skor dalam grup. Adapun rumus yang digunakan adalah:

$$
M=\frac{\sum x}{N}
$$

Keterangan:

$M=$ nilai rata-rata

$\sum x=$ jumlah skor

$N=$ jumlah skor grup (Leady, P, D \& Ormrod, J, 2010: 266).

Selain itu, dilakukan analisis hasil dokumentasi gambar foto masing-masing kegiatan pembelajaran dalam setiap siklus digunakan untuk melengkapi hasil observasi.

\section{Hasil dan Pembahasan}

\subsection{Hasil Penelitian}

Data penelitian yang sudah dianalisis mendapatkan hasil sebagai pedoman dalam pembahasan. Hasil penelitian berdasarkan hasil ob- servasi yang dilakukan setiap siklusnya kemampuan membaca mengalami peningkatan.

Peningkatan proses pembelajaran terjadi dari siklus 1 ke siklus 2, pada siklus 2 guru sudah memanfaatkan media lift the flap book dengan baik untuk menjelaskan kepada siswa dalam kegiatan pembelajaran membaca dan bercerita. Guru memberikan kesempatan kepada siswa untuk membaca dan bercerita, dan membimbing dengan memanfaatkan media lift the flap book. Selain itu kriteria penilaian membaca dan bercerita yang akan dilakukan oleh guru sudah disampaikan kepada siswa.

Siswa sudah tertarik membaca dan bercerita dengan bantuan media lift the flap book, secara berkelompok, serta mendengarkan setiap penjelasan yang dilakukan oleh guru. Hasil secara keseluruhan pada proses pembelajaran membaca mengalami peningkatan dari siklus 1 ke siklus 2, hal ini ditunjukkan dengan skor pengamatan proses pembelajaran meningkat rata-ratanya dari 39 menjadi 54 . Dengan demikian mengalami peningkatan skor pengamatan sebesar 15. Setelah kegiatan proses pembelajaran membaca di pertemuan kedua siklus 2 dilakukan penilaian. Penilaian yang dilakukan adalah untuk mengetahui peningkatan hasil proses pembelajaran siswa. Hasil observasi dan penilaian kemampuan membaca terangkum dalam tabel 3 dan 4 .

Tabel berikut merupakan rangkuman dari hasil observasi proses pembelajaran membaca yang dilakukan .

Tabel 3

Rangkuman Hasil Pengamatan Aktivitas Pembelajaran Guru dan Siswa Siklus 1 dan siklus 2

\begin{tabular}{ccccc}
\hline \multirow{2}{*}{ No. } & \multirow{2}{*}{ Pertemuan } & \multicolumn{2}{c}{$\begin{array}{c}\text { Skor pada Sik- } \\
\text { lus }\end{array}$} & \\
\cline { 3 - 4 } & & 1 & 2 & \\
\cline { 3 - 4 } 1. & I & 36 & 48 & 12 \\
2. & II & 42 & 60 & 18 \\
& Jumlah & 78 & 108 & 30 \\
& Rata-rata & 39 & 54 & 15 \\
\hline
\end{tabular}


Peningkatan proses pembelajaran membaca dan bercerita siswa kelas I SD Negeri Puren Depok Sleman dapat dilihat pad grafik berikut.

Grafik 1

Peningkatan Skor Rata-rata Proses Pembelajaran dari Siklus 1 ke Siklus 2

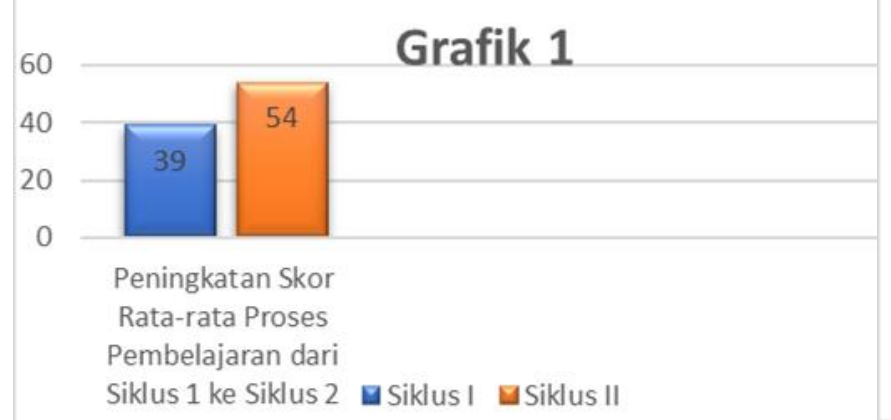

Hasil peningkatan nilai setiap aspek kemampuan membaca bercerita siswa kelas I SD Negeri Puren terangkum dalam tabel berikut.

Tabel 3

Peningkatan Setiap Aspek Kemampuan Membaca

\begin{tabular}{clcc}
\hline \multirow{2}{*}{ No. } & \multicolumn{1}{c}{$\begin{array}{c}\text { Aspek-aspek } \\
\text { Membaca }\end{array}$} & \multicolumn{2}{c}{ Nilai Rata-rata } \\
\cline { 3 - 4 } & \multicolumn{1}{c}{ Siklus 1 } & Siklus 2 \\
\hline 1. & Lafal & 73 & 82 \\
2. & Intonasi & 71 & 72 \\
3. & Kelancaran & 80 & 82 \\
4. & Kejelasan & 80 & 82 \\
5. & Membaca dengan & 77 & 95 \\
& utuh & & \\
\hline
\end{tabular}

Peningkatan kemampuan membaca siswa SD Negeri Puren Depok Sleman kelas I siklus 1 dan siklus 2 dapat dilihat pada grafik berikut.
Grafik 2

Peningkatan Nilai Rata-rata dan Prosentase Peningkatan Nilai di atas Rata-rata Kemampuan Membaca dari Siklus 1 ke Siklus 2

\section{Grafik 4}

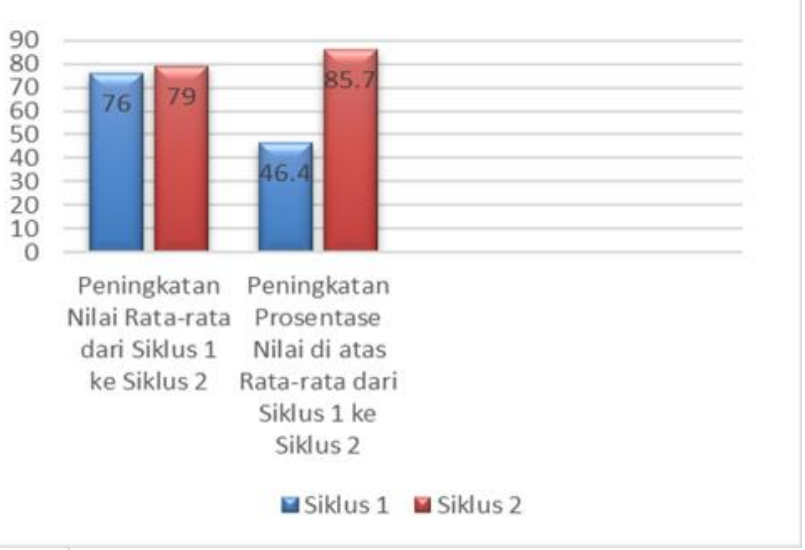

Hasil tes kemampuan membaca siswa nilai rata-rata meningkat dari 76 menjadi 79 . Siswa yang nilainya di atas nilai rata-rata jumlahnya meningkat dari 13 siswa menjadi 23 siswa. Selain itu, persentase siswa yang nilainya di atas nilai rata-rata meningkat sebesar $39,3 \%$ yaitu dari $46,4 \%$ menjadi $85,7 \%$.

\subsection{Pembahasan}

Hasil proses pembelajaran membaca dengan menggunakan media lift the flap book, mengalami peningkatan. Peningkatan kemampuan membaca berdasarakan indikator membaca siswa mengalami peningkatan dari siklus 1 ke siklus 2 . Sebagaian besar lafal siswa dalam membaca sudah baik, tidak menunjukkan ciri kedaerahan. Intonasi siswa dalam membaca sudah tepat dalam penggunaan intonasi. Sebagian besar siswa sudah lancar saat membaca di depan kelas, suara jelas tidak terbata-bata, serta tepat dalam pengucapan kata-kata dan kalimat sederhana. Kemampuan membaca secara keseluruhan sebagian siswa sudah mengalami peningkatan. 
Peningkatan ini disebabkan siswa sudah memperhatikan kegiatan pembelajaran menggunakan media lift the flap book. Media yang digunakan menyenangkan bagi siswa, karena membuat siswa aktif. Penggunaan media lift the flap book akan membantu siswa untuk aktif dalam pembelajaran. Media lift the flap book di dalamnya ada beberapa kata yang tersembunyi dalam jendela buku yang bisa dibuka, untuk mengetahui kata yang tersembunyi tersebut siswa dituntut untuk membuka.

Lift the flap book merupakan media yang selain ada bacaan dilengkapi pula dengan gambar. Selaras dengan penelitian MartinKerry dkk, bahwa partisipasi siswa pada kegiatan pembelajaran dapat ditingkatkan menggunakan media gambar (Martin-Kerry dkk, 2017: 10). Penelitian (Rasch and Schnotz 2009) juga menunjukkan bahwa partisipasi pembelajaran dapat ditingkatkan dengan menggunakan media gambar. Selain itu media lift the flap book siswa akan termotivasi untuk membaca isi buku karena siswa terlibat langsung dalam kegiatan pembelajaran ((Rasch and Schnotz 2009). Sejalan dengan pendapat Conradie et al., yang menunjukkan bahwa kepercayaan dan motovasi anak dapat ditingkatkan dengan pelibatan siswa secara penuh (Conradie dkk, 2019: 11).

Pembelajaran kemampuan membaca siswa kelas 1 SD Negeri Puren untuk meningkatkan proses dan hasil pembelajaran menggunakan bantuan media lift the flap book. Penggunaan media lift the flap book dalam proses pembelajaran membaca siklus 1 dan 2 aktifitas guru dan siswa mengalami peningkatan. Siswa semakin tertarik untuk membaca, dan mulai merangkai kata-kata yang ada dalam media yang digunakan. Penggunaan media dapat menimbulkan daya tarik kepada siswa untuk belajar membaca. $\mathrm{Di}$ dalam membaca ada beberapa faktor yang dapat mempengaruhi anak-anak antara lain jenis atau media baca dan instruksi dari guru.
Media pembelajaran memberikan manfaat bagi guru maupun siswa yaitu media membantu guru dalam menyajikan materi dan apabila pembelajaran berpusat pada siswa sebagai pengguna utama dalam menggunakan media. Selain itu, penelitian yang dilakukan oleh Triyanto \& Mustadi, (2020: 11), pembelajaran melalui PBL berbantuan lift the flap book dapat meningkatkan motivasi siswa dalam membaca. Siswa sangat tertarik dengan media yang digunakan, sehingga akan memunculkan motivasi untuk membaca. Penelitian ini memperkuat hasil penelitian Suriani, B, and Efendi, (2015: 76) siswa terangsang untuk mencoba dan dan mengamati dengan yang dilihatnya saat pembelajaran, dengan alat/peraga yang digunakan saat pembelajaran. Siswa merasa yang dilihat mudah untuk diikuti, ditiru dan dilakukan sesuai petunjuk guru.

Hasil dari penelitian masih ada siswa yang mengalami kesulitan dalam membaca berdasarkan indikator kemampauan membaca. Pada indikator intonasi nilai yang diperoleh sudah mengalami peningkatan, namun nilianya masih dibawah dari yang diharapkan yakni 75. Siswa kelas 1 SD Negeri Puren kemampuan membaca pada indikator membaca secara utuh siswa sudah dapat melakukan dengan baik.

Siswa yang mengalami kesulitan merupakan siswa yang memerlukan pendampingan khusus. Sekolah Dasar Negeri Puren merupakan salah satu sekolah inklusi, sehingga ada beberapa siswa berkebutuhan khusus, dan diantara siswa tersebut ada yang duduk di kelas 1. Namun secara keseluruhan kemampuan membaca siswa sudah mengalami peningkatan. Hal ini terbukti bahwa terjadi peningkatan nilai rata-rata dari 76 di siklus 1 menjadi 79 di siklus 2 dan siswa yang nilainya divatas rata-rata meningkat dari $46,4 \%$ di siklus 1 menjadi 85,7\% di siklus 2. Dengan demikian penelitian ini diakhiri pada pertemuan 
kedua siklus 2 karena sudah sesuai dengan target yang ditetapkan.

\section{Simpulan}

Berdasarkan analisis data dan pembahasan yang telah dilakukan disimpulkan sebagai berikut. Peningkatan hasil proses pembelajaran kemampuan membaca penggunaan media lift the flap book dapat meningkatkan proses pembelajaran pembelajaran kemampuan membaca siswa kelas 1 SD Negeri Puren Depok Sleman. Siswa semakin tertarik untuk melakukan kegiatan membaca. Guru dapat memanfaatkan media untuk kegiatan pembelajaran kemampuan membaca selain buku paket dari sekolah. Siswa semakin berani untuk membaca isi dari bacaan dalam buku.

Peningkatan hasil proses pembelajaran kemampuan membaca. Siswa mengalami peningkatan kemampuan membaca berdasarkan aspek-aspek membaca dari 8 aspek membaca, aspek lafal, kelancaran, kejelasan, membaca dengan utuh sudah berhasil mencapai target yaitu yang mencapai nilai rata-rata kelas ke atas sebanyak $\geq 75 \%$, sedangkan intonasi belum mencapai target pencapaian prosentase siswa yang nilainya sama dengan nilai rata-rata kelas ke atas.

Secara keseluruhan hasil peningkatan nilai rata-rata dari 76 di siklus 1 menjadi 79 di siklus 2 dan siswa yang nilainya divatas ratarata meningkat dari $46,4 \%$ di siklus 1 menjadi $85,7 \%$ di siklus 2. Dengan demikian penelitian ini diakhiri pada pertemuan pertama siklus 2 karena sudah sesuai dengan target yang ditetapkan.

\section{Daftar Pustaka}

Arikunto, Suharsimi. 2006. "Prosedur Penelitian: Suatu Pendekatan Paraktik." Rineka Cipta.

Bluemel, Nancy Larson \& Rhonda Harris Taylor. 2012. “Pop-up Books: A Guide for
Teachers and Librarians." California: $A B C$ CLJO-LLC.

Conradie, Peter D., Bram B. Van Acker, Ellen De Vos, and Jelle Saldien. 2019. "And Self - Confidence." International Journal of Technology and Design Education (0123456789). DOI: https://doi.org/10.1007/s10798-01909531-7.

Cowie, Helen. 2010. "Emotional Literacy in the Early Years C." University of Surrey, UK. E-Mail: H.Cowie@surrey.Ac.Uk Ó 2012, Helen Cowie 78-80. DOI: http://dx.doi.org/10.1080/02643944.201 2.651281 .

Depdiknas. 2018. "Pengembangan Media Pembelajaran."

Fajarsih Darusuprapti; Haryanto. 2019. "Peningkatan Keterampilan Menulis Cerita Pendek Berbasis Karakter Menggunakan Media Pembelajaran VideoScribe." Prosiding Seminar Nasional Bulan Bahasa (Semiba) 2019 265-70.

Konza, Deslea. 2014. "Teaching Reading: Why the 'Fab Five' Should Be the 'Big Six .'" Australian Journal of Teacher Education, 39(12) 39(12). DOI: http:/ /dx.doi.org/10.14221/ajte.2014v39 n12.10.

Kucukoglu, H. 2013. "Improving Reading Skills through Effective Reading Strategies." Procedia - Social and Behavioral Sciences 70:709-14. DOI: 10.1016/j.sbspro.2013.01.113.

Leady, P, D \& Ormrod, J, E. 2010. “Practical Research Planning and Design, Ninth Edition.Pdf." 1-500. 
Martin-kerry, Jacqueline, Peter Bower, Bridget Young, Jonathan Graffy, Rebecca Sheridan, Ian Watt, Paul Baines, Catherine Stones, Jennifer Preston, Steven Higgins, Carrol Gamble, and Peter Knapp. 2017. "Developing and Evaluating Multimedia Information Resources to Improve Engagement of Children , Adolescents, and Their Parents with Trials ( TRECA Study ): Study Protocol for a Series of Linked Randomised Controlled Trials." 1-12. DOI: 10.1186/s13063-017-1962-z.

Oey, Fanny Wiliyanto, Heru Dwi Waluyanto, and Asnar Zacky. 2011. "Perancangan Buku Interaktif Pengenalan dan Pelestarian Sugar Glider Di Indonesia Bagi Anak 7-12 Tahun." 1-11.

Petscher, Yaacov, Stephanie Al Otaiba, Jeanne Wanzek, Brenna Rivas, Yaacov Petscher, Stephanie Al Otaiba, and Jeanne Wanzek. 2017. "Scientific Studies of Reading The Relation Between Global and Specific Mindset With Reading Outcomes for Elementary School Students The Relation Between Global and Specific Mindset With Reading." Scientific Studies of Reading 00(00):1-16.

Rasch, Thorsten and Wolfgang Schnotz. 2009. "Interactive and Non-Interactive Pictures in Multimedia Learning Environments: Effects on Learning Outcomes and Learning Efficiency." Learning and Instruction 19(5):411-22.

Sudharsan, Madhu. 2018. “Factors Influencing Early Reading Skills among Pre-School Children in Malaysia." India's Higher Education Authority UGC Approved List of Journals Serial Number 49042 18(49042):140-46.
Suggate, Sebastian. 2009. "Research into Early Reading Instruction and Luke Eff Ects in the Development of Reading." 11:17-20.

Suriani, Suriani, Sahrudin B, and Efendi Efendi. 2015. "Peningkatan Kemampuan Membaca Permulaan Siswa Kelas 1 SDN Ginunggung Melalui Media Kartu Huruf Kec. Galang." Jurnal Kreatif Tadulako Online 4(10):62-77.

Tomkins, Geil \& Hoskisson, K. 1995. Language Arts Content and Teaching Strategis. Ohio: Merrill. An imprantof Prentice Hall.

Triyanto, Yuli and Ali Mustadi. 2020. "The Effect of Problem-Based Learning Model Assisted by Lift The Flap Book: Enhancing Reading Motivation of $3 \mathrm{Rd}$ Grade Students." 8(March):151-66. DOI: http:/ /dx.doi.org/10.17478/jegys.664120

W. James Pophan \& Kenneth A. Sirothik. 1973. Rata-Rata Diperoleh dengan Menjumlahkan Semua Skor Mentah dan Membagi dengan Jumlah Yang Dijumlahkan dengan Jumlah Skor dalam Grup. Second Edi. New York: Harper \& Row.

Widodo, Sri Adi. 2018. "Selection of Learning Media Mathematics for Junior School Students." TOJET: The Turkish Online Journal of Educational Technology 17(1):154-60. 